\title{
SOME EFFECTS OF HUMAN GROWTH HORMONE ON RENAL HEMODYNAMICS AND ON TUBULAR PHOSPHATE TRANSPORT IN MAN *
}

\author{
By JACQUES CORVILAIN AND MAURICE ABRAMOW With THE TECh NICAL ASSISTANCE \\ oF A. BERGANS
}

(From the Clinique Médicale et Laboratoire de Médecine Expérimentale de l'Hôpital Brugmann et de la Fondation Médicale Reine Elisabeth, Université Libre de Bruxelles)

(Submitted for publication November 29, 1961 ; accepted February 22, 1962)

It has been repeatedly shown that human growth hormone (HGH) affects phosphorus metabolism in patients with hypopituitarism and in normal subjects. Injection of $\mathrm{HGH}$ leads to a decrease of urinary phosphorus within a day (1-3). Whereas serum phosphorus does not change or rises only slightly in short-term experiments (1), it has been reported that it rises with long-term treatment (4). Whereas the decrease of urinary phosphorus associated with an unchanged or rising serum phosphorus suggests that growth hormone decreases renal clearance of phosphate, the mechanism for these effects has not been defined. In the dog, growth hormone has been shown to raise glomerular filtration rate (GFR), renal plasma flow (RPF), tubular maximal secretion of para-aminohippurate ( $\left.\mathrm{Tm}_{\mathrm{PAH}}\right)(5-7)$, and tubular maximal reabsorption of sulfate $\left(\mathrm{Tm}_{\mathrm{SO}_{4}}\right)$ (8). Effects on renal phosphate clearance have not been reported. The present study was undertaken to determine whether HGH affects the ability of the human kidney to reabsorb phosphate. For this purpose, maximum tubular phosphate reabsorption $\left(\mathrm{Tm}_{\mathrm{PO}_{4}}\right)$ was measured before and after administration of growth hormone. Effects of the hormone on GFR and on RPF were also studied.

The results indicate that $\mathrm{HGH}$ increases the phosphate Tm, the GFR, and the RPF.

\section{MATERIAL AND METHODS}

Growth hormone was extracted from human pituitary glands removed at autopsy and stored in acetone. Two lots were used in this study : one prepared by Dr. Maurice Raben, and one prepared by ourselves with Raben's method (9). The HGH was dissolved in $1.5 \mathrm{ml}$ of $0.1 \mathrm{~N}$

* This work was supported in part by grants from the Paul Govaerts Foundation and the Lekime-Ropsy Foundation.
$\mathrm{HCl}$ per $100 \mathrm{mg}$ of dry powder, and then diluted with distilled water until $100 \mathrm{mg}$ was contained in $25 \mathrm{ml}$ of solution. The final $\mathrm{pH}$ of the solution was about 3.5.

Injections were given intramuscularly once a day at 7 a.m. Eleven male subjects were studied: one dwarf with hypopituitarism, one hypophysectomized former acromegalic, and nine subjects free of endocrinologic disorders. Brief case descriptions are given in the Appendix.

Plan of study. All patients were hospitalized and received constant diets throughout the study. Water intake was ad libitum. After an adjustment period of 5 days, urine was collected in 24-hour pools for determination of nitrogen, phosphorus, sodium, potassium, and calcium. GFR, $\mathrm{Tm}_{\mathrm{PO}_{4}}$ and $\mathrm{RPF}$ were measured at the end of the control period which lasted 5 days, and on the fourth day of treatment with growth hormone. Treatment with growth hormone was begun on the third day after the control determination of renal function and was continued for 4 days.

Renal studies were begun at 8:30 a.m., after food had been withheld for 14 hours. The bladder was catheterized with a rubber catheter, which remained in place throughout the experiment. (For two individuals, VP and DP, who were able to void at will, catheterization was omitted.) Large amounts of water were given by mouth to maintain urine volume. Blood was drawn for blank determination and for control blood phosphorus, and a priming dose of inulin and phosphate was administered ( 25 to $50 \mathrm{ml}$ of a 10 per cent inulin solution; 30 to $80 \mathrm{ml}$ of a solution containing $\mathrm{Na}_{2} \mathrm{HPO}_{4} \cdot 12 \mathrm{H}_{2} \mathrm{O}, 10$ per cent, and $\mathrm{KH}_{2} \mathrm{PO}_{4}, 0.75$ per cent, infused over a period of 3 minutes). A sustaining solution containing inulin and phosphate was then infused at a rate designed to give a slowly rising serum phosphorus value in the range of 7 to $11 \mathrm{mg}$ per $100 \mathrm{ml}$ and a serum inulin value of about $30 \mathrm{mg}$ per $100 \mathrm{ml}$. Thirty minutes after the infusion was begun, urine was collected for seven consecutive periods, varying in length from 10 to 15 minutes. During the first, third, fifth, and seventh periods, blood was drawn from an antecubital vein. Each period was ended by washing the bladder with distilled water and air. At the end of the seventh period, the infusion of inulin and phosphorus was stopped, and some of the subjects were given a priming dose of $\mathrm{PAH}(2 \mathrm{ml}$ of a 20 per cent solution) followed by a sustaining infusion 
TABLE I

Mean 24-hour urinary excretion before $(A)$ and during $(B)$ administration of human growth hormone

\begin{tabular}{|c|c|c|c|c|c|c|c|c|c|c|c|}
\hline \multirow[b]{2}{*}{ Case } & \multirow[b]{2}{*}{ Diagnosis } & \multicolumn{2}{|c|}{ Nitrogen } & \multicolumn{2}{|c|}{ Potassium } & \multicolumn{2}{|c|}{ Phosphorus } & \multicolumn{2}{|c|}{ Calcium } & \multicolumn{2}{|c|}{ Sodium } \\
\hline & & A & B & A & B & A & B & A & B & A & B \\
\hline & & \multicolumn{2}{|c|}{ g/day } & \multicolumn{2}{|c|}{$m E q / d a y$} & \multicolumn{2}{|c|}{$m g / d a y$} & \multicolumn{2}{|c|}{$m g / d a y$} & \multicolumn{2}{|c|}{$m E q / d a y$} \\
\hline \multirow{2}{*}{$\begin{array}{l}\text { VHF } \\
\text { BL }\end{array}$} & $\begin{array}{l}\text { Pituitary dwarfism } \\
\text { Acromegaly, inactive }\end{array}$ & 6.5 & 3.4 & 35 & 14 & 665 & 218 & 79 & 78 & 30 & 4 \\
\hline & (hypophysectomized) & 15.2 & 13.6 & 47 & 41 & 1,030 & 900 & 142 & 329 & 176 & 158 \\
\hline LR & Pulmonary tuberculosis & 12.9 & 9.2 & 54 & 49 & 895 & 417 & 248 & 268 & 233 & 197 \\
\hline $\mathrm{SA}$ & Pulmonary tuberculosis & 15.6 & 8.7 & 105 & 50 & 1,142 & 564 & 222 & 255 & 227 & 181 \\
\hline VP & Chronic alcoholism & 11.0 & 7.3 & 49 & 33 & 960 & 580 & 77 & 84 & 128 & 87 \\
\hline $\mathrm{VC}$ & Rectocolic polyposis & 8.8 & 5.7 & 55 & 19 & 602 & 321 & 199 & 264 & 78 & 54 \\
\hline SG & Saturnism, latent & 12.3 & 9.0 & 45 & 25 & 854 & 703 & 87 & 101 & 184 & 120 \\
\hline RM & Pulmonary tuberculosis & 13.6 & 10.1 & 60 & 38 & 760 & 541 & 281 & 386 & 151 & 105 \\
\hline DP & Pharyngitis & 17.4 & 13.6 & 92 & 64 & 1,035 & 995 & 125 & 150 & 219 & 226 \\
\hline $\mathrm{DJ}$ & Colitis & 21.5 & 14.8 & 79 & 31 & 1,007 & 542 & 281 & 322 & 249 & 145 \\
\hline GL & Emphysema & 9.0 & 11.8 & 59 & 56 & 647 & 763 & 89 & 178 & 141 & 170 \\
\hline
\end{tabular}

such as to maintain a plasma level of PAH of 1.5 to 3.5 $\mathrm{mg}$ per $100 \mathrm{ml}$. Thirty minutes after this infusion was begun, urine was collected over four periods of about 10 minutes' duration. Blood was drawn for PAH determination during the first, second, and fourth periods.

Chemical methods. Inulin was determined in plasma and urine by the method of Roe, Epstein and Goldstein (10) ; PAH by the method of Smith and associates (11); inorganic phosphorus by the method of Fiske and Subbarow (12); calcium by the method of Tisdall and Kramer (13) ; nitrogen by micro-Kjeldahl ; and potassium and sodium on a flame photometer.

Calculations. Plasma phosphate, inulin, and PAH concentrations were plotted against time to permit interpolation. Plasma values for a given collection period were assumed to be those 2.5 minutes before the midpoint (14). Clearances of inulin and PAH were calculated in the usual manner. Filtered phosphorus was calculated as the product of the inulin clearance and plasma $P$. Reabsorbed $\mathrm{P}$ was calculated as the difference between the filtered and the excreted $P$.

In each experiment, a maximal tubular reabsorption rate of phosphorus $\left(\mathrm{Tm}_{\mathrm{P}}\right)$ is thought to have been reached. This can be inferred from data in Table II (ratio of filtered $\mathrm{P}$ to $\mathrm{Tm}$ has always been higher than 2).

Reabsorption of $\mathrm{P}\left(\mathrm{T}_{\mathrm{P}}\right)$ per unit of filtrate was also calculated as $\mathrm{Tm}_{P}$ divided by GFR.

\section{RESULTS}

Clinical effects of $H G H$. HGH caused transient pain at the site of injection. Four patients complained of moderate anorexia during the treatment period.

Metabolic effects of HGH (Table I). Table I shows the effects of HGH compared to control figures on urinary nitrogen, potassium, phosphorus, calcium, and sodium in the 11 studies. In ten patients there was a marked reduction of urinary $\mathrm{N}$ during treatment; in nine of them the decrease in urinary $\mathrm{N}$ was accompanied by decreases in urinary $\mathrm{K}, \mathrm{P}$, and $\mathrm{Na}$; in one of them (DP) there was a decrease in urinary $\mathrm{N}$ and $\mathrm{K}$ but no appreciable change in urinary $\mathrm{P}$ or $\mathrm{Na}$. In one patient (GL) $\mathrm{HGH}$ did not induce retention of $\mathrm{N}$, $\mathrm{K}, \mathrm{P}$, or Na. In this patient (vide infra) serum phosphorus did not change. Inasmuch as $\mathrm{HGH}$ failed to induce $\mathrm{N}$ retention in this patient, the data are excluded from the statistical analysis. Calciuria increased in ten patients during $\mathrm{HGH}$ treatment.

In Patient BL, who formerly had acromegaly and diabetes, with relief of diabetes after hypophysectomy, $\mathrm{HGH}$ was prolonged for 2 days after completion of the renal function studies. The serum glucose, which had remained normal until that time, increased, and glycosuria appeared and continued for several days after $\mathrm{HGH}$ was stopped.

The serum phosphorus rose during treatment with $\mathrm{HGH}$ in eight patients (Table II). The difference between groups was significant at the 5 per cent level.

Effects of $H G H$ on renal function (Table II). The effects of $\mathrm{HGH}$ on renal function are compared with control determinations in Table II. As with the metabolic data, the results for Patient GL, who showed no metabolic response to $\mathrm{HGH}$, are excluded from the statistical analysis.

Glomerular filtration rate. GFR increased in nine of the subjects. Results were significant at the 0.1 per cent level. 


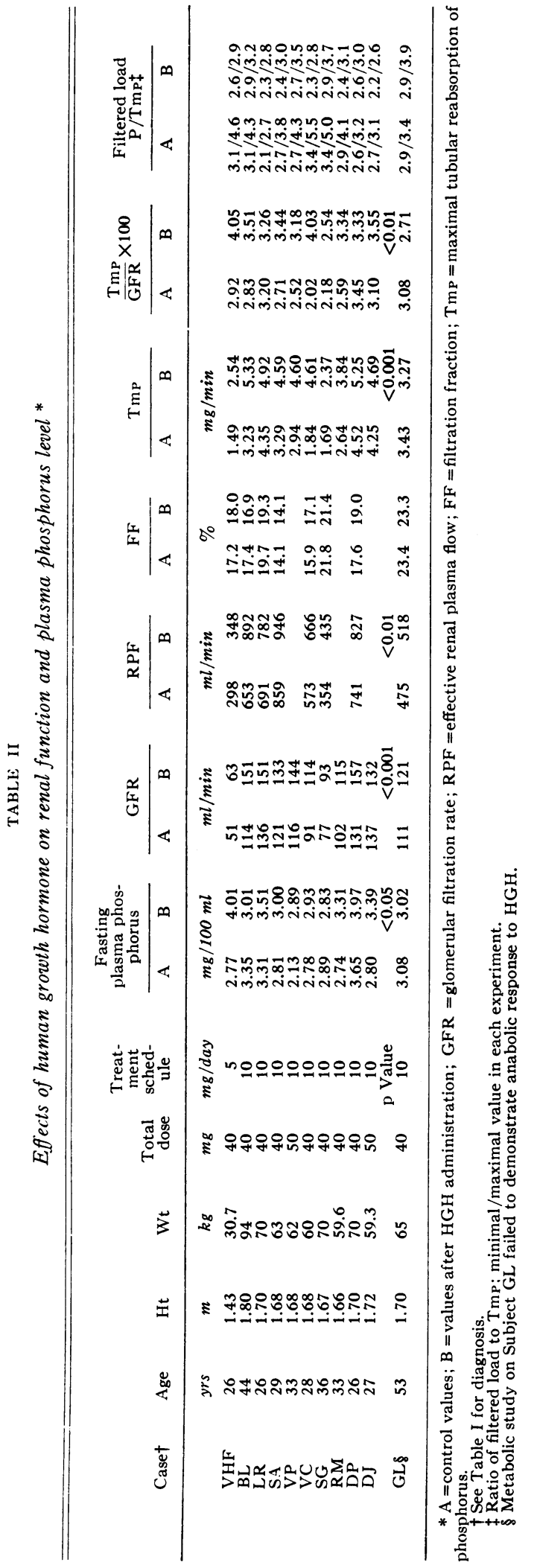

Renal plasma flow. Renal plasma flow was measured in seven of the studies. It increased in all subjects with $\mathrm{HGH}$, and the change was significant at the 1 per cent level. In all subjects the rise in RPF was of the same order of magnitude as the rise in GFR, and the filtration fraction did not change significantly.

Phosphorus Tm. The $\mathrm{Tm}_{\mathrm{PO}_{4}}$ increased markedly in all patients, and the change was significant at the 0.1 per cent level. The $\mathrm{Tm}_{\mathrm{P}}$ per unit of GFR increased in nine of the subjects and the change was significant at the 0.1 per cent level. It is of interest that Subject DP, in whom Tm per unit GFR did not increase, was the one who showed the least $\mathrm{P}$ retention with $\mathrm{HGH}$. In Subject GL, who showed no metabolic response to $\mathrm{HGH}$, there was a small rise in GFR and $\mathrm{RPF}$, but $\mathrm{Tm}_{\mathrm{P}}$ and $T \mathrm{~m}_{\mathrm{P}}$ per unit of GFR fell slightly (Table II).

\section{DISCUSSION}

It is known from previous studies $(1-3,15)$ that human growth hormone, in contrast to animal growth hormone, is metabolically active in man. The present results confirm these findings: in most of our subjects, $\mathrm{HGH}$ induced marked retention of $\mathrm{N}, \mathrm{K}$, and $\mathrm{P}$, suggesting protein anabolism. Only one subject, the oldest of the series, failed to exhibit this anabolic response to HGH.

A pronounced $\mathrm{Na}$ retention was also generally seen. Although this phenomenon is not yet clearly understood, the adrenal cortex does not seem to play a determinant role in its appearance (2).

The increased calciuria that we observed is a frequent finding in $\mathrm{HGH}$ studies. Its magnitude appears to be related to HGH dosage (15). The mechanism by which hypercalciuria is elicited by $\mathrm{HGH}$ remains controversial: an increased intestinal absorption of $\mathrm{Ca}$, which has been observed with HGH (1), is sometimes insufficient to account for this rise in urinary $\mathrm{Ca}(2)$ and bones have been postulated as a source of this extra calcium (16).

A rising serum phosphorus with $\mathrm{HGH}$, without concomitant rise in urinary phosphorus, suggested that the phenomenon might be of renal origin, and studies of renal phosphate clearance were accordingly instituted. It is generally be- 
lieved that phosphate excreted in the urine represents the excess of the phosphate filtered over that reabsorbed by the tubules. It is also generally believed that phosphate reabsorption reaches $\mathrm{Tm}$ values at high plasma levels and that $\mathrm{Tm}$ is independent of the GFR (17-19). Some investigators, however, have suggested that phosphate reabsorption is dependent upon the amount filtered at all plasma levels, and have attributed differences in reabsorption to differences in the number of nephrons functioning (20). To measure the renal capacity for excretion of $P$, we have used the classical test of $\mathrm{Tm}_{\mathrm{P}}$ under phosphate loading with simultaneous determination of GFR by inulin clearance.

Our control values for $\mathrm{Tm}_{\mathrm{P}}$ are somewhat lower than those found by many investigators, perhaps because our patients suffered from chronic diseases and prolonged hospitalization. Our control values do not, indeed, fall outside the range found by Thompson and Hiatt (19) in normal young male subjects.

In the subjects who exhibited a metabolic response to $\mathrm{HGH}, \mathrm{Tm}_{\mathrm{P}}$ increased as early as 4 days after initiation of treatment. The GFR and the $\mathrm{RPF}$ increased pari passu, and the filtration fraction did not change. If $\mathrm{Tm}_{\mathrm{P}}$ is indeed independent of GFR, these results indicate that HGH affects kidney function in two ways: it enhances maximal tubular reabsorption of $\mathrm{P}$, and it increases $\mathrm{RPF}$ and GFR. If, on the other hand, $T \mathrm{~m}_{P}$ is indeed a function of filtered phosphate, the rise in $\mathrm{Tm}_{\mathrm{P}}$ observed in these studies might result solely from the increase of filtration rate. However, the rise in $\mathrm{Tm}_{\mathbf{P}}$ was relatively greater than the rise in filtered phosphate, indicating an action of $\mathrm{HGH}$ on $\mathrm{P}$ reabsorption independent of any action on filtration of $\mathrm{P}$.

It has been suggested that glomeruli may function intermittently in the normal subject. Accordingly, the rise in GFR and RPF with $\mathrm{HGH}$ might indicate an increase in the active nephron population. This again would explain some of the increase of $\mathrm{Tm}_{\mathrm{P}}$ observed in these studies. It would not explain the relative excess of the increase in $\mathrm{Tm}_{\mathrm{P}}$ over that of GFR which, as stated above, suggests a tubular effect of $\mathrm{HGH}$ on $\mathrm{P}$ reabsorption.

The data clearly indicate that $\mathrm{HGH}$ increases the reabsorption of $\mathrm{P}$ per milliliter of filtrate. In these conditions, the net result of $\mathrm{HGH}$ action on renal hemodynamics and tubular transport of $\mathrm{P}$ must be, at constant level of $\mathrm{P}$ in plasma, an initial fall in urinary excretion of $P$. This fall would not be expected to occur if the rise in $\mathrm{Tm}_{P}$ were smaller than, or of the same magnitude as, the rise in GFR and the resulting increase in filtered $P$. It is of interest that Patient DP, who showed an increase in $\mathrm{Tm}_{\mathrm{P}}$ but no rise in $\mathrm{Tm}_{\mathrm{P}}$ per milliliter of filtrate, was the only subject in this study who did not show appreciable retention of $\mathrm{P}$ with $\mathrm{HGH}$, in spite of retention of $\mathrm{N}$. We can reasonably conclude that the decrease in phosphaturia that we have observed in the metabolic studies is of renal origin.

Gershberg (21) also concluded that HGH induces retention of $\mathrm{P}$ by increasing renal reabsorption of $\mathrm{P}$. In five patients in whom clearances of $\mathrm{P}$ and of creatinine were determined for 24-hour periods, he found that the ratio TRP/GFR was increased with $\mathrm{HGH}$.

In our study, an elevation of serum $\mathrm{P}$ was seen as early as 4 days after the initiation of treatment with HGH. The increment was small, but in the face of marked synthesis of protoplasm, which might be expected to enhance tissue avidity for $\mathrm{P}$, it gains in significance. Our data suggest that an increase in tubular reabsorption of $\mathrm{P}$ per milliliter of filtrate is responsible for this rise in serum $P$.

The present studies do not necessarily indicate that the effect of $\mathrm{HGH}$ on tubular reabsorption of $\mathrm{P}$ is a direct one. The parathyroids are known to affect $\operatorname{Tm}_{\mathbf{P}}(22,23)$ and $\mathrm{HGH}$ might affect the renal tubules by inhibiting parathyroid activity. Indeed the enhancement of gastrointestinal absorption of calcium, which may occur during treatment with HGH (1), might be expected to inhibit parathyroid activity. It has been shown, however, that retention of $\mathrm{P}$, with rise of serum $\mathrm{P}$, can be induced by $\mathrm{HGH}$ in a subject without parathyroids (24), so that a change in parathyroid activity cannot alone explain this action of $\mathrm{HGH}$.

Our finding that $\mathrm{HGH}$ increases GFR and $\mathrm{RPF}$ in man confirms previous reports in the dog (5-7), and the previous reports of a similar effect, as judged from 24-hour creatinine clearance, in man (21). It agrees well also with the reports (25-27) that GFR and RPF may be high in patients with acromegaly. 


\section{SUMMARY AND CONCLUSIONS}

Human growth hormone was administered to 11 human subjects under conditions of metabolic balance regimen. Significant increase in glomerular filtration rate and renal plasma flow was observed. In ten subjects there was a rise in maximal tubular reabsorption of $\mathrm{P}$; in nine, the $\mathrm{P}$ reabsorption per milliliter of glomerular filtrate rose as well. The nine subjects who showed the increase of $\mathrm{P}$ reabsorption per milliliter of glomerular filtrate also retained $\mathrm{P}$ with human growth hormone. On the fourth day of treatment with human growth hormone, serum $\mathrm{P}$ was raised in eight subjects. It is concluded that growth hormone is responsible for the elevation of serum $\mathrm{P}$ found in acromegaly, and that this is effected by an increase in the reabsorption of filtered $P$.

Growth hormone thus appears to have a direct effect upon tubular transport of $P$. This effect appears to be opposite to that of parathyroid hormone.

\section{ACKNOWLEDGMENT}

We are much indebted to Dr. F. C. Bartter for having reviewed our manuscript. We wish to thank Dr. M. S. Raben for his generous assistance in preparing human growth hormone. We are also most grateful to Prof. L. Desclin and Dr. C. Gompel for providing us with an ample supply of human pituitaries, and to Prof. P. A. Bastenie for the opportunity to study some of the patients in his department.

\section{APPENDIX}

The case material was as follows.

VHF, age 26: dwarf with idiopathic hypopituitarism who had not received any hormonal treatment for the last 9 years.

BL, age 44: man with acromegaly. Because of severe diabetes, hypophysectomy had been performed 2 years previously. After the operation, hyperglycemia and glycosuria had disappeared completely and no insulin was required. Cortisone, $25 \mathrm{mg}$ per day, was given as substitutive therapy and maintained during the whole study with $\mathrm{HGH}$.

LR, age 26; SA, age 29 ; RM, age 33 : men with pulmonary tuberculosis (under treatment) in good general condition.

SG, age 36: man with chronic occupational lead poisoning and mild impairment of renal function.

GL, age 53: man with emphysema and asthma.

$\mathrm{VC}$, age 28: man with rectocolic polyposis and intermittent diarrhea.

DP, age 26: man convalescent from pharyngitis.

VP, age 33: man with chronic alcoholism.

DJ, age 27: man convalescent from acute colitis.

\section{REFERENCES}

1. Henneman, P. H., Forbes, A. P., Moldawer, M., Dempsey, E. F., and Carroll, E. L. Effects of human growth hormone in man. J. clin. Invest. 1960, 39, 1223.

2. Ikkos, D., Luft, R., and Gemzell, C. A. The effect of human growth hormone in man. Acta endocr. (Kbh.) 1959, 32, 341.

3. Beck, J. C., McGarry, E. E., Dyrenfurth, I., Morgen, R. O., Bird, E. D., and Venning, E. H. Primate growth hormone studies in man. Metabolism 1960, 9, 699.

4. Raben, M. S. in Discussion of Ikkos, D., and Luft, R. Aspects of metabolic action of human growth hormone. Ciba Found. Coll. Endocr. 1960, 13, 132.

5. White, H. L., Heinbecker, P., and Rolf, D. Enhancing effects of growth hormone on renal function. Amer. J. Physiol. 1949, 157, 47.

6. De Bodo, R. C., and Sinkoff, M. W. The role of growth hormone in carbohydrate metabolism. Ann. N. Y. Acad. Sci. 1953, 57, 23.

7. Davis, J. O., Howell, D. S., Laqueur, G. L., and Peirce, E. C., II. Renal hemodynamic function, electrolyte metabolism and water exchange in adrenalectomized-hypophysectomized dogs. Amer. J. Physiol. 1954, 176, 411.

8. Gershberg, H., and Gasch, J. Effect of growth hormone on sulfate $\mathrm{Tm}$, urea clearance and fasting blood glucose. Proc. Soc. exp. Biol. (N. Y.) 1956, 91, 46.

9. Raben, M. S. Preparation of growth hormone from pituitaries of man and monkey. Science 1957, 125, 883.

10. Roe, J. H., Epstein, J. H., and Goldstein, N. P. Photometric method for the determination of inulin in plasma and urine. J. biol. Chem. 1949, 178, 839.

11. Smith, H. W., Finkelstein, N., Aliminosa, L., Crawford, B., and Graber, M. The renal clearances of substituted hippuric acid derivatives and other aromatic acids in dog and man. J. clin. Invest. 1945, 24, 388.

12. Fiske, C. H., and Subbarow, Y. The colorimetric determination of phosphorus. J. biol. Chem. 1925, $66,375$.

13. Tisdall, F. F., and Kramer, B. Methods for the direct quantitative determination of sodium, potassium, calcium, and magnesium in urine and stools. J. biol. Chem. 1921, 48, 1.

14. Smith, H. W. The Kidney. Structure and Function in Health and Disease. New York, Oxford Univ. Press, 1951, p. 42.

15. Clinical Endocrinology Committee of the Medical Research Council. The effectiveness in man of human growth hormone. Lancet 1959, 1, 7.

16. Fraser, R., and Harrison, M. The effect of growth hormone on urinary calcium excretion. Ciba Found. Coll. Endocr. 1960, 13, 135. 
17. Lambert, P. P., Van Kessel, E., and Leplat, C. Etude sur l'élimination des phosphates inorganiques chez l'homme. Acta med. scand. 1947, 128, 386.

18. Schiess, W. A., Ayer, J. L., Lotspeich, W. D., and Pitts, R. F. The renal regulation of acid base balance in man. II. Factors affecting the excretion of titratable acid by the normal human subject. J. clin. Invest. 1948, 27, 57.

19. Thompson, D. D., and Hiatt, H. H. Renal reabsorption of phosphate in normal human subjects and in patients with parathyroid disease. J. clin. Invest. 1957, 36, 550.

20. Longson, D., Mills, J. N., Thomas, S., and Yates, P. A. Handling of phosphate by the human kidney at high plasma concentrations. J. Physiol. (Lond.) 1956, 131, 555.

21. Gershberg, H. Metabolic and renotropic effects of human growth hormone in disease. J. clin. Endocr. 1960, 20, 1107.
22. Jacobs, E., and Verbanck, M. The renal action of parathyroid hormone in man. Acta med. scand. 1953, 145, 143.

23. Hiatt, H. H., and Thompson, D. D. The effects of parathyroid extract on renal function in man. $\mathrm{J}$. clin. Invest. 1957, 36, 557.

24. Gershberg, H. Metabolic and renotropic effects of human growth hormone in disease (abstract). First Int. Congr. Endocrinology, Advance $\mathrm{Ab}-$ stracts of Short Communications, Copenhagen, 1960, p. 255.

25. Heller, B. I., Smith, R. E., and Lubin, R. I. Renal functional status in patients with acromegaly (abstract). J. Lab. clin. Med. 1954, 44, 811.

26. Ikkos, D., Ljunggren, H., and Luft, R. Glomerular filtration rate and renal plasma flow in acromegaly. Acta endocr. (Kbh.) 1956, 21, 226.

27. Gershberg, H., Heinemann, H. O., and Stumpf, H. H. Renal function studies and autopsy report in a patient with gigantism and acromegaly. J. clin. Endocr. 1957, 17, 377. 